\title{
Investment Management in an Inflationary World
}

\author{
by Dr. Hans J. Mast *
}

The upheaval of the world economy in the last ten recessionary years has basically changed the task of investment management. Certainly, institutional investors, who are bound by government regulations or company by-laws to invest almost exclusively in their own country, have been much less affected. But for investors who are not subject to such restrictions the world of investment looks entirely different today. This truth is particularly evident of Swiss banks, which have constantly been forced by the limitations of their domestic financial markets to offer investment advice on an international scale. And it is their experience that forms the background for the following remarks.

Seen from the Swiss vantage point, the economic background of investment policy appears to have experienced five chief, partly interrelated changes.

\section{Basic changes in economic environment}

1) Inflation. As regards the inflationary forces, the present thrust of economic policy, the current trend of public opinion, and the marked decline in inflation rates do pose the question of whether inflation will continue to be a major factor influencing investment policy in the immediate future. Generally, the expectation expressed at the Philadelphia conference in spring that it would decline has been proven correct and barring unforeseeable political upheavals it is likely to continue its downward course at least during the next 12 to 24 months (graph I).

This issue will be taken up again. There is, however, no doubt that inflation has strongly influenced, if not been the cause of the four other major trends affecting investment policy, i.e.

2) lower growth of GNP. This and the concomitant squeeze of profit margins resulted largely from the oil shock and the ensuing restrictive policy necessary to

* Executive Vice-President and Economic Advisor of Credit Suisse. Lecture presented to a workshop during the "Eagle Lodge Conference" on "Facing Risk in changing economies and societies" - Philadelphia — 29/30 April 1982. 
Graph I. Trends in consumer prices

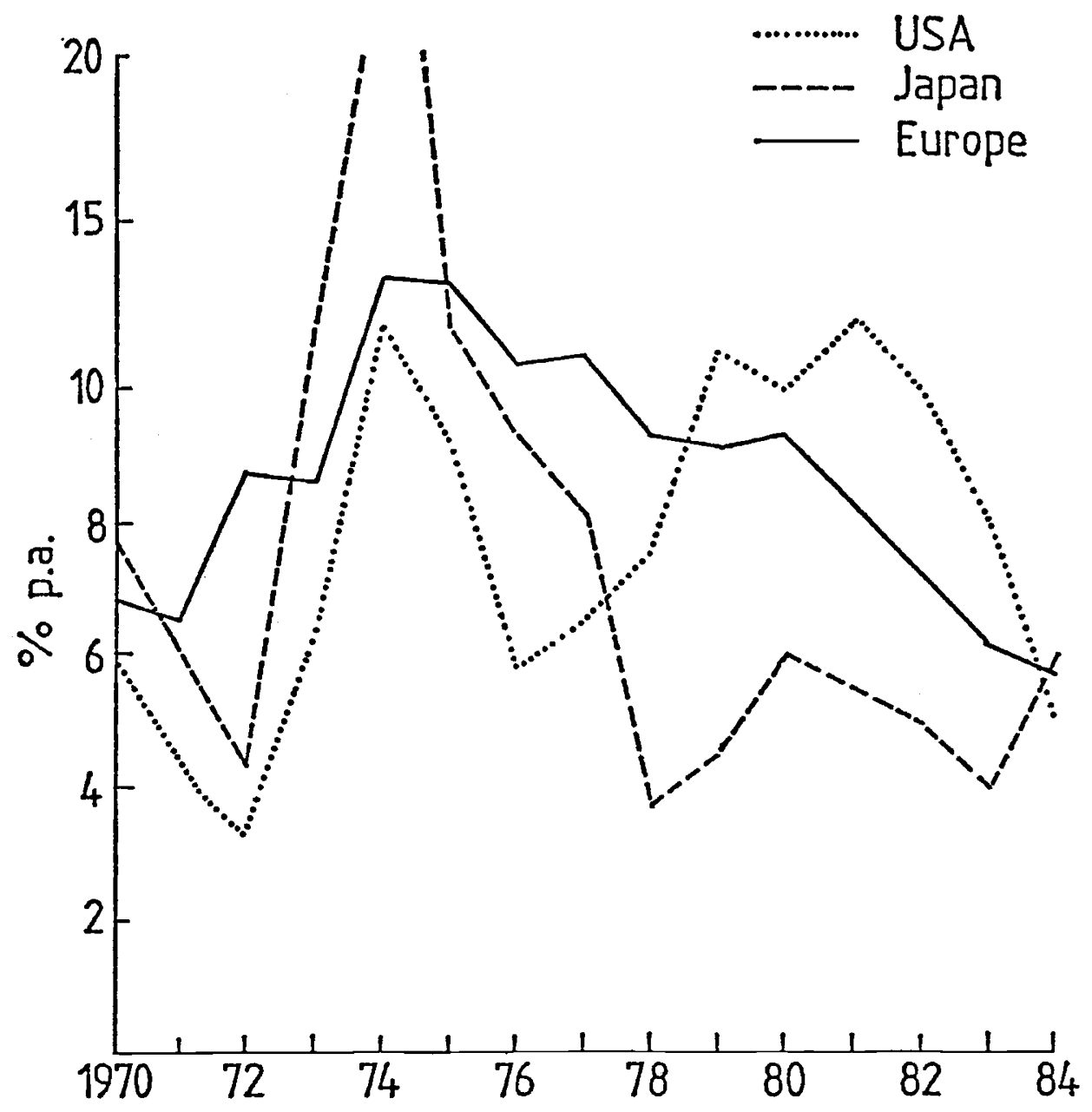

combat inflationary forces and other disruptive influences, notably the huge increase in international indebtedness (graph II).

3) The increase and volatility of interest rates. Although nominal interest rates increased almost everywhere since the sixties, the movement exhibited three particular features. First, the increase in nominal rates has differed widely from country to country. Secondly, it has of late been generally much faster than that of inflation rates. Accordingly, real interest rates - i.e. nominal interest rates less inflation rates - have moved up sharply in most countries and in some cases to historical peaks. Thirdly, in the wake of these developments the volatility of financial markets has grown 
strikingly. Most worrying is the increase in volatility of short- and long-term interest rates. This is in itself not a reason for an increased fragility of the world economy. But they leave it more susceptible to external shocks.

In view of this trend and the increased real and nominal interest differential between various countries it would have been natural for international flows or capital to expand substantially. But this trend was countered by another major element in the international economy, namely,

4) floating exchange rates. Their volatility in general not only exceeded that of stock and bond markets. It was also much more difficult to predict as it exhibited no

\section{Graph II. GNP growth of industrial countries $1970=100$}

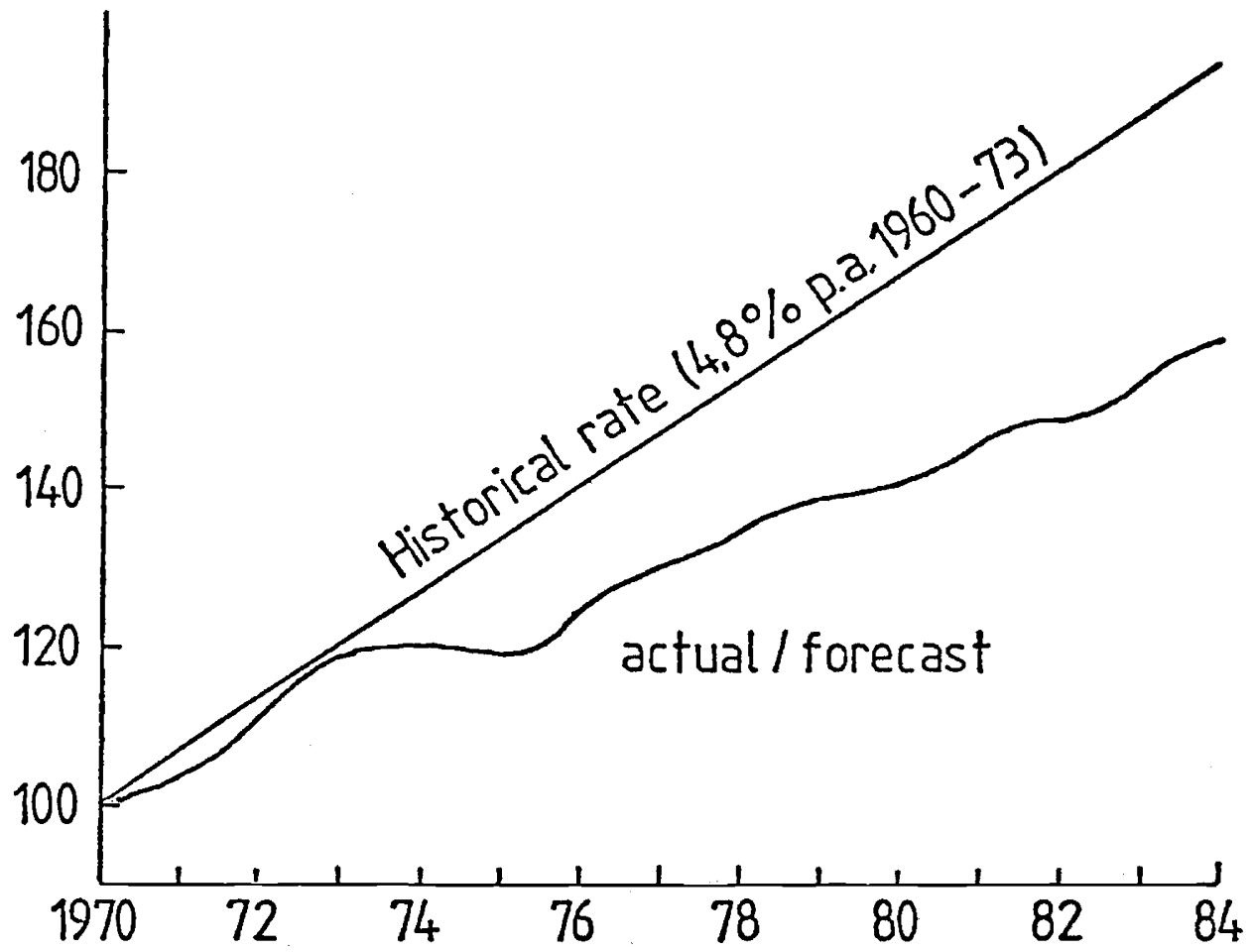

systematic correlation to that of other economic variables, like interest rates, inflation differentials or current account surpluses and deficits (table I). In view of this situation, investment management was confronted with additional risks and problems of performance calculations. These difficulties were compounded by the fifth characteristic feature of our time, namely,

5) economic and financial policy instability or inappropriate policy procedures, due partly to increased international tensions, often abrupt changes in domestic policies and unexpected commodity price shocks. 
Table I : Standard deviations of monthly changes

(Source: Alexander Swoboda, Stabilising a fragile international financial system SUERF-Colloquium, Vienna, April 22-24, 1982)

\begin{tabular}{|c|c|c|c|c|c|c|c|c|}
\hline & 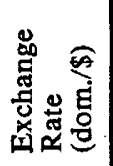 & 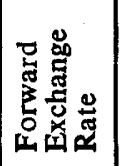 & 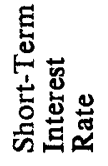 & 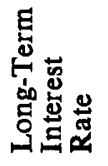 & 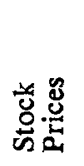 & 起完 & 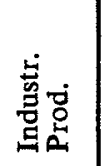 & 总 \\
\hline $\begin{array}{l}\text { 1. U.S.A. }{ }^{2} \\
1966,2-81,9 \\
1966,2-71,1 \\
1971,1-73,1 \\
1974,1-79,7 \\
1979,9-81,9\end{array}$ & $\begin{array}{l}- \\
- \\
-\end{array}$ & $\begin{array}{l}- \\
- \\
-\end{array}$ & $\begin{array}{r}.883 \\
.387 \\
.393 \\
.484 \\
2.158\end{array}$ & $\begin{array}{l}.276 \\
.166 \\
.209 \\
.165 \\
.593\end{array}$ & $\begin{array}{l}.037 \\
.035 \\
.028 \\
.040 \\
.042\end{array}$ & $\begin{array}{l}.0034 \\
.0020 \\
.0016 \\
.0030 \\
.0028\end{array}$ & $\begin{array}{l}.0097 \\
.0073 \\
.0056 \\
.012 \\
.012\end{array}$ & $\begin{array}{l}.030 \\
.027 \\
.031 \\
.034 \\
.021\end{array}$ \\
\hline $\begin{array}{l}2 . \quad U . K .^{3} \\
1966,2-81,9 \\
1966,2-71,1 \\
1971,1-73,1 \\
1974,1-79,7 \\
1979,9-81,9\end{array}$ & $\begin{array}{l}.021 \\
.020 \\
.014 \\
.023 \\
.028\end{array}$ & $\begin{array}{l}.026 \\
.019 \\
.019 \\
.030 \\
.033\end{array}$ & $\begin{array}{l}.602 \\
.272 \\
.430 \\
.772 \\
.657\end{array}$ & $\begin{array}{l}.431 \\
.173 \\
.289 \\
.604 \\
.455\end{array}$ & $\begin{array}{l}.059 \\
.040 \\
.043 \\
.077 \\
.041\end{array}$ & $\begin{array}{l}.008 \\
.005 \\
.004 \\
.009 \\
.008\end{array}$ & $\begin{array}{l}.016 \\
.010 \\
.024 \\
.018 \\
.010\end{array}$ & $\begin{array}{l}.022 \\
\text { n.a. } \\
.021 \\
.020 \\
.028\end{array}$ \\
\hline $\begin{array}{l}\text { 3. Germany } \\
1966,2-81,9 \\
1966,2-71,1 \\
1971,1-73,1 \\
1974,1-79,7 \\
1979,9-81,9\end{array}$ & $\begin{array}{l}.023 \\
.012 \\
.009 \\
.032 \\
.031\end{array}$ & $\begin{array}{l}.078 \\
.007 \\
.010 \\
.031 \\
.037\end{array}$ & $\begin{array}{l}\text { n.a. } \\
\text { n.a. } \\
\text { n.a. } \\
\text { n.a. } \\
\text { n.a. }\end{array}$ & $\begin{array}{l}.239 \\
.182 \\
.197 \\
.226 \\
.363\end{array}$ & $\begin{array}{l}.034 \\
.037 \\
.038 \\
.029 \\
.025\end{array}$ & $\begin{array}{l}.003 \\
.003 \\
.003 \\
.003 \\
.003\end{array}$ & $\begin{array}{l}.018 \\
.022 \\
.017 \\
.014 \\
.016\end{array}$ & $\begin{array}{l}.028 \\
.024 \\
.032 \\
.030 \\
.032\end{array}$ \\
\hline $\begin{array}{l}\text { 4. Japan } 4 \\
1966,2-81,9 \\
1966,2-71,1 \\
1971,1-73,1 \\
1974,1-79,7 \\
1979,9-81,9\end{array}$ & $\begin{array}{c}.021 \\
0 \\
.013 \\
.024 \\
.034\end{array}$ & $\begin{array}{l}.032 \\
\text { n.a. } \\
.009 \\
.030 \\
.037\end{array}$ & $\begin{array}{l}.451 \\
.259 \\
.226 \\
.468 \\
.723\end{array}$ & $\begin{array}{l}.251 \\
.007 \\
.069 \\
.221 \\
.475\end{array}$ & $\begin{array}{l}.035 \\
.034 \\
.039 \\
.030 \\
.022\end{array}$ & $\begin{array}{l}.009 \\
.007 \\
.007 \\
.010 \\
.007\end{array}$ & $\begin{array}{l}.014 \\
.011 \\
.013 \\
.013 \\
.020\end{array}$ & $\begin{array}{l}.041 \\
.043 \\
.043 \\
.040 \\
.045\end{array}$ \\
\hline $\begin{array}{l}\text { 5. Switzerland } \\
1966,2-81,9 \\
1966,2-71,1 \\
1971,1-73,1 \\
1974,1-79,7 \\
1979,9-81,9\end{array}$ & $\begin{array}{c}.025 \\
0 \\
.014 \\
.028 \\
.034\end{array}$ & $\begin{array}{l}.031 \\
.003 \\
.015 \\
.037 \\
.043\end{array}$ & $\begin{array}{l}\text { n.a. } \\
\text { n.a. } \\
\text { n.a. } \\
\text { n.a. } \\
\text { n.a. }\end{array}$ & $\begin{array}{l}.159 \\
.110 \\
.129 \\
.163 \\
.218\end{array}$ & $\begin{array}{l}.042 \\
.045 \\
.040 \\
.042 \\
.030\end{array}$ & $\begin{array}{l}.005 \\
.004 \\
.004 \\
.005 \\
.004\end{array}$ & $\begin{array}{l}\text { n.a. } \\
\text { n.a. } \\
\text { n.a. } \\
\text { n.a. } \\
\text { n.a. }\end{array}$ & $\begin{array}{l}.021 \\
.021 \\
.018 \\
.021 \\
.027\end{array}$ \\
\hline
\end{tabular}


These various influences which contributed to augmenting economic and financial uncertainty have, of course, several adverse consequences. The information content of prices' signals diminishes and the response of the economy may well be reduced significantly. Long-term investment becomes more risky, which induces the financial system to introduce innovations of a bridging character like floating rate bonds or a substantial shortening of maturity structure. As debt and real interest rates have risen substantially, the possibility of debt defaults is increasing, and pessimistic expectations as to the economic and financial prospects become more prevailing.

\section{Changed task of investment management}

While the evolution just described is in some respects typical of every recession that follows an inflationary period it contains certain unique aspects which have completely revolutionized the traditional concepts of financial investment policy and management. True, these basic tasks still consist in investing financial assets as profitably as possible in the face of existing uncertainties. But the uncertainties, i.e. the unforeseeable dangers, have increased to an extent that calls for a radical shift of emphasis in the analysis of investment management problems.

In fact, even the traditional assumption that the best and most suitable way to invest savings and similar assets generally consisted in acquiring shares or bonds has been invalidated by recent experience. High-yielding bank deposits, money market investments, gold, real estate and other so-called real assets have gained in importance as investment instruments during the inflationary times of the recent past.

Moreover, the traditional type of security analysis, too, has lost some of its value as a guide to investment policy. As a matter of fact, security analysis is based on the ultimate assumption that the condition of the world economy will not alter radically. Under such circumstances it is reasonable to believe that the prospects of an enterprise and its equities or bonds can reliably be assessed by a study of the company's situation and financial key figures, such as price/earnings ratios, market shares, the quality of a company's management or similar factors.

The economic prerequisites of these assumptions have vanished of late. True, members of the brotherhood of security analysts have in theory always underlined the importance of the economic framework. However, in practice, this acknowledgement has generally not gone far beyond a rather schematic assessment of cyclical swings, the accompanying interest rate movements and certain sectorial and technological trends. Security analysis, however, did not, and could not take into account the changes that have occurred in the world's economic structure over the last 10-15 years. This is not the fault of security analysis but due to the fact that there never was - and there is not now - a solid theoretical link between its microeconomic approach and the overall macroeconomic system.

Partly due to this structural weakness, the practical results of investment management based simply on security analysis have been rather disappointing of late. Witness the growth fad of some years back - which ended disastrously for most investors. The theory that shares in companies with substantial land and raw materials reserves offer 
the best inflationary hedge met with a similar fate. The meticulous analysis of the quality of bonds made a rather futile impression on the general public at a time when interest rates were well below inflation rates and long-term investors at least should have been dissuaded from the acquisition of such paper. And what use is, after all, an impressive return for instance from a US dollar bond when the investor simultaneously witnesses a sharp fall of the dollar against other currencies, which turns the handsome return from his dollar investment into a loss, if calculated in a more stable currency, such as German marks or Swiss francs. The magnitude of potential optical illusions resulting from this situation can be gauged, for example, from the price movement of the units of internationally-oriented bond funds managed by Credit Suisse. While prices in Swiss francs have fallen by approximately $30 \%$ over the last ten years, those in US dollars have increased by around $10 \%$ - notwithstanding the massive increase in interest rates during the period in question, a performance, incidentally, that is to my knowledge - far superior to that of any comparable US mutual. This success was of course due not to the shrewd selection of securities, but above all to currency management.

Actually, calculated in US dollars, the Swiss and Japanese markets with their low-yielding bonds and shares have shown an outstanding performance during the last ten years, due not least to the hardness of their respective currencies. But this experience has robbed another cherished theory of security analysis of most of its practical meaning, namely the traditional theory, according to which low yields generally imply low risks, and high yields high risks. Against this background whole libraries - from the best-sellers of our modern Adam Smith to serious scientific works - have been written about the demise of security analysts, who, chewing their nails look gloomily at a world that largely eludes analysis through their traditional tools.

\section{Increased emphasis on economics}

Given this situation, the reaction of practical investment managers was as usual more balanced than that of theoretical approaches. They fully recognized the continuing value of security analysis for a meaningful selection of bonds and shares to be acquired. But they simultaneously stressed the overwhelming necessity to supplement it by careful in-depth analysis of the new risk elements inherent in the present international environment, such as political tensions, inflationary trends, prospects of foreign exchange and interest rate movements, balance of payments problems, and their implication for investment management.

Parallel to this, a certain change of attitude appears to have taken place in European investment advisory boards. While at the end of the sixties discussions in these committees largely focussed on the securities analysts' assessment of the comparative quality and potential of individual securities, it is now primarily concerned with political, economic and foreign exchange considerations, with the examination of ideas emanating from security analysis taking second place.

In keeping with these changes, economists - once mere assistants to security analysts - now carry increased weight in investment advisory groups. Historically 
speaking, this change is by no means unique. In times of unrest and upheaval, microeconomic considerations always lose in importance as compared to macroeconomic ones. Significantly, the crisis periods shortly before the end of the eighteenth century and of the early thirties of our century have lent fresh impulses and significance to economics has indicated by the names of the original Adam Smith or David Ricardo during the earlier and John Maynard Keynes during the more recent period.

Parallel to these shifts in emphasis, all investment advisory institutions and services have vigorously pushed their macroeconomic and political studies in the past ten years or so. Completely new research units and technical systems including the extensive use of computerized information and simulation systems have been introduced for this purpose. Incidentally, this was a fairly natural thing to do for Continental European allround banks which needed such analysis not only for investment advice, but also for their other operations, notably their international loan and new issues business.

This expansion of basic economic research and evaluations was concentrated chiefly on the three major areas. First, the systematic and comparative assessment of country risks - the so-called " country rating" — which of course also provides results and evaluations as to the investment quality of particular countries.

Second, the observation of inflation, foreign exchange and interest rate trends in all major investment countries has been intensified and integrated into unified systems in order to establish any possible feedback effects on the other variables. Simultaneously, the economic policy stances, notably in the field of monetary and foreign exchange policy, as well as possible reactions to changes in the overall economic and political environment are being examined attentively.

Third, with the development of sophisticated economic and currency forecasting models and with rapid technological changes, investment advisory services generally also stepped up and expanded their research into the situation and prospects of individual economic sectors. In this context, considerable attention was also devoted notably by European banks to analysing the structure and particularities of certain real assets of special interest to investors, like real estate or gold. These broadened and expensive macroeconomic analysis in recent years lent a number of additional dimensions to the emphasis of investment policy. New aids, such as scenario programs to limit investment risks and make them more immediately recognizable have been developed.

These elaborate studies in the function and behaviour of national economies and their financial markets made certain basic rules of investment policy apparent again which, though valid for all time, have tended to be largely overlooked under the stable conditions of the first two post-war decades. These rules include, to mention only a few, the following :

1) Calculate the performance of your investments always in the hardest currency during the period under review. For it is only in this way that the potential and actual result of any investment can be assessed realistically.

2) Invest, if all other conditions are equal, only in the country with the highest real rate of interest. For high real interest rates generally lead to adjustments either 
in the form of a decline in nominal interest rates or of a hardening of the national currency - two developments which are both beneficial to the investor. The problem lies, of course, with the condition " if all things are equal ". But in this respect careful economic analysis supplemented by some additional technical tools, like interest sensitivity curves, can contribute to the solution of practical problems.

3) As regards countries for investment, nations with stability-oriented policies such as Switzerland, Japan and West Germany, offer advantages. They find expression above all in the hardness of the currency. The countervailing factors are comparatively low interest rates and correspondingly high capitalization rates. A purely formal comparison of these rates, however, with those of inflation-ridden countries must lead to wrong conclusions and has therefore to be avoided since they do not take into account the currency risks involved. Conversely, it is also true that investment prospects should be particularly bright on the bond and stock markets of countries like the US today, that are seriously starting to put their economic and financial house in order after a prolonged inflationary period.

4) A fourth major rule is that under today's economic policy environment (progressive taxes, price controls, moral suasion), shares generally lose more or less the quality as inflation hedges which is commonly ascribed to them. In order to protect real values investors have tended to turn to gold since the middle of the seventies with results which were not always completely satisfactory. However, it was often overlooked that the acquisition of gold as an inflation hedge can only be justified as long as basic economic policies remain inflation-oriented, which has no longer been the case in most industrialised countries since the early eighties.

On the other hand gold can sensibly be purchased also as a type of insurance premium against uninsurable investment risks of our times, like wars, revolutions or sudden new surges of inflation. In this case, investments in the yellow metal should be limited to a relatively small portion of the total portfolio, say 10 to $15 \%$. In the spirit of averaging, however, when the gold price is rising, holdings should be reduced to the extent that their value has exceeded the original investment goal ; conversely, with prices falling, new purchases should gradually be made in order to maintain the target portfolio relationship. Considerations of a similar nature could also be applied to the acquisition of other real assets, such as commodities or real estate.

5) Which economic sectors are the most promising ones can no longer be established on a world-wide basis as uniformly as heretofore. At present it is necessary for such studies to take account of the structure of national economies, their employment leveis, the real value of their currency, the level of interest and inflation rates and similar factors in order to arrive at realistic forecasts as to the prospects of individual economic branches in investment countries. Accordingly, recommendations and advice in this field have to vary much more strongly today from nation to nation than ten or twenty years ago.

6) In view of today's numerous indefinable risks, diversification of portfolio holdings not only by form of investment and type of security, but also by investment country and currency seems absolutely essential. True, economists and securities analysts have no sure-fire tips to give in this regard, but can point out obvious errors and evident conclusions. Consequently, in their periodic reviews of investment policy 
investment managers regularly establish certain percentages as to the preferable distribution of portfolios according to countries, currencies, economic branches and the type of security to be acquired.

These and other basic rules may sound to many like truism. This may be true, but it by no means detracts from their significance under present circumstances. In fact, they markedly differ in character from the investment advice based simply on the results of security analysis which formerly dominated the field almost exclusively.

\section{Conclusions}

Economists are naturally proud of the increasing recognition of the practical aspects of their activity. Yet they have no cause for euphoria. They realize that their enhanced importance is primarily a corollary to the uncertainty that inflation and its consequences have injected into the world economy. Today's stress on combating inflation, and the adoption of policies known as "supply-side economics" are designed to bring back a more stable situation, where inflation and exchange rate movements would no longer be major factors in investment management. If such conditions could be reached, securities analysis would win back a large part of the terrain that it has lost over the past fifteen years. Economists would not complain. They know that markets function most successfully when insecurities do not require them constantly to gaze into the crystall ball of the future but when conditions are reliable enough for manufacturers and investors to base their decisions simply on the signals given by prices and profits. 